\title{
Theories of information, communication and knowledge: a multidisciplinary approach
}

Fidelia Ibekwe-SanJuan ; Thomas M Dousa

O presente livro baseia-se no colóquio EPICIC, dedicado à Epistemologia comparativa da Informação e comunicação, realizado em 8 de Abril de 2011 em Lyon (http://www.epicic.org/en/node/16), financiado pelo Institute des Sciences de la Communication (através do Programa PIR - Programme interdisciplinaire de recherche), e que deu lugar a um conjunto de reflexões ${ }^{1}$ e textos emanando de especialistas de vários domínios - Ciência da informação, Sociologia de comunicação, Semiótica, Filosofia da informação -, agora editados por Fidelia Ibekwe-San Juan e Thomas Dousa. O título reportanos à relação entre as teorias da informação, da

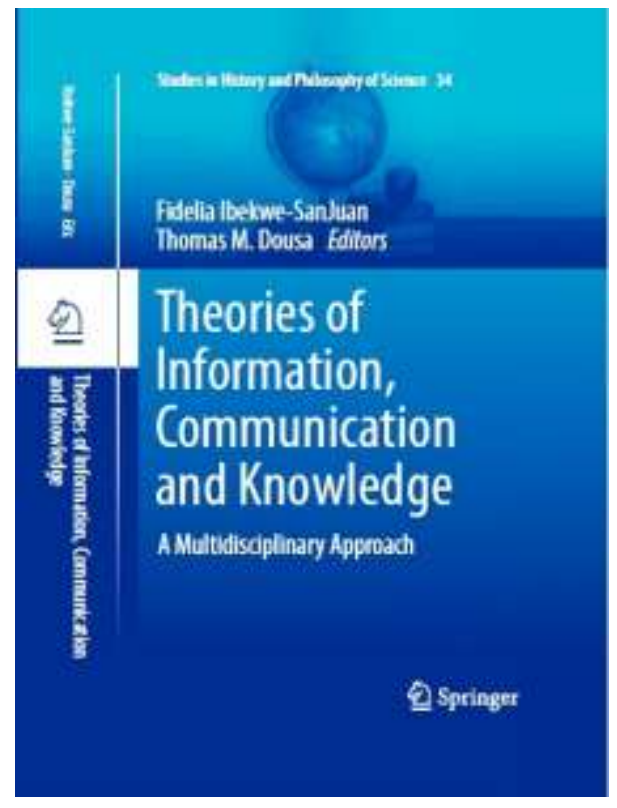
comunicação e do conhecimento o que, numa sociedade mediatizada e informacional, se torna cada vez mais premente de analisar e debater.

Fidelia Ibekwe-San Juan, professora associada de Estudos de Informação e comunicação na University of Lyon 3, é autora de uma vasta obra em teoria da ciência da informação, des envolvendo investigação em epistemologia da informação e da comunicação, tendo nos últimos anos participado em vários grupos de reflexão interdisciplinar, nomeadamente em painéis com Fuller Steve, Hjorland Birger, Ma Lai, Tennis Josepj e Warner Julian no 76 th Annual Meeting of ASIST\&T (Canada, 2013) - Uncovering Epistemological Assumptions Underlying Research in Information Studies e Crossing the boundaries in Information Science: perspectives on interdisciplinarity. Ao prefaciar a obra de David Bowen e Lynn Robinson, Introduction to Information Science (2012), esta autora observava que a 
informação "is a slippery and ubiquitous concept" e que os livros dedicados a esta temática "go a long way in distinguishing the contributions this field has made to the global information society" (pp.xxiii/xxiv).

O seu trabalho com Thomas Dousa, doutorado pela University of Illinois e com investigação em história da ciência da informação, é recente, resultando numa complementaridade reflexiva, comprovada no texto introdutório (pp.1-21), organizado como um guia de contextualização das diversas perspetivas apresentadas e tendo como objetivo estabelecer interligações entre as concepções teóricas da informação e comunicação na resposta a cinco questões-chave: - o que é a informação? - o que é o conhecimento? Como sabemos que conhecemos algo? - Como construímos o significado a partir das perceções das coisas? - Como comunicamos este significado a outros?

Desta forma, é sob o pano de fundo dos conceitos de informação e conhecimento, cuja natureza é discutida por alguns autores dos textos, que são apresentadas várias propostas de análise da heterogeneidade das formas e instrumentos que têm vindo a emergir e que lançam um olhar retrospetivo sobre o percurso epistemológico trilhado ao longo das três últimas décadas. São abordados os paradigmas físico e cognitivo até ao paradigma social, aqui representado por Birjer Hjorland e Soren Brier; bem como a aproximação do paradigma hermenêutico à semiótica, ao construtivismo e à cibernética, na linha de pensamento de Cornelius e do conceito de cibersemiótica de Brier, considerando a relação entre signo, objeto e intérprete como dinâmica e adaptável a diversos contextos e ampliando o conceito de interpretação para além do conhecimento humano ao relacioná-lo com todo o tipo de processo seletivo. Desta confluência teórica surgiu a necessidade de uma teoria unificada da informação que reúna e entrecruze os diversos conceitos de informação e os relacione com a realidade social e natural que possibilita a sua existência, como tem vindo a ser defendida por Hofkirchner desde 1999.

A visão interdisciplinar para a Ciência da Informação teve um primeiro impulso em 1983 com a obra de Machlup e Mansfield The study of information interdisciplinary messages, que apresentava nove áreas de especialização centradas na informação: a ciência cognitiva, informática, inteligência artificial, linguística, ciência da informação, cibernética, teoria da informação e teoria de sistemas. Foi considerada na época uma obra de grande impacto como o salientam Hartel, Fuller, Szostak e Bonnici (2012): "by illuminating the concerns, similarities, and differences of these related domains the book established one of the first and most lucid geographies of information as an interdisciplinary academic enterprise".

O interesse pelo tema foi continuado, entre outros, na obra de Neill (1992) Dilemmas in the study of information: exploring the boundaries of information science, e por Abbott (2001) com a obra Chaos of disciplines, mas com focos de discussão diferenciados. 
O leitor da presente obra é conduzido a olhar e a interessar-se por algumas destas transformações e desafios, com implicações no nosso conhecimento profissional. Entre os temas abordados, vários caminham para a consolidação conceptual como, por exemplo, a visão transdisciplinar da teoria da informação, desenvolvida por Soren Brier (pp. 23-49) ou a teoria unificada da informação (pp.51-69), a cargo de Wolfgang Hofkirchner, ou ainda a perspetiva semiótica da comunicação humana, esquematizada e debatida por Winfried Noth (pp.97-119). A sua leitura resulta naquilo que Ibekwe-San Juan e Dousa consideram ser uma experiência informativa (p. 201) para todos os interessados, explorando as formas variadas como a informação e a comunicação são percecionadas em diferentes disciplinas e como esta dinâmica afeta as teorias do conhecimento.

O trabalho teórico - definindo, concetualizando, discutindo - é uma atividade crucial no estabelecimento da interdisciplinaridade, destacando-se a abordagem de David Bawden e Lynn Robinson no sentido de valorizar o estudo das relações entre conceitos em vários domínios, mesmo que não derive dessa discussão uma conceção unificada da informação (Mind the gap: transitions between concepts of information in varied domains pp. 121-141). Estes autores adotam a imagem de Luciano Floridi de que a natureza da informação constitui um arquipélago composto por ilhas-dominio (Perception and testimony as data providers, pp. 71-95), sendo necessário estudar as suas ligações e o valor que aportam para outras disciplinas, na perspetiva de outro autor participante nesta obra, Jonathan Furner (Information without information studies, pp. 143-179)

Luciano Floridi apresenta as relações entre informação e conhecimento, usando a evolução do conceito de informação semântica (significativa e credível) até ao conhecimento, desenvolvendo a questão: " if knowledge is accounted information, what happens when we apply this definition to the analysis of perceptual knowledge and knowledge by testimony?"

A escolha das temáticas visam relançar o debate em torno das mudanças epistemológicas como é o caso do texto de lan Cornelius (Epistemological challenges for information science: constructing information, pp. 181-203) que retoma e alarga o seu anterior texto de referência Theorizing information for information science (2002), na linha das 13 metateorias ${ }^{2}$ de uma importante autora, Marcia Bates (2010), e a abordagem conceptual de Birger Hjorland (Information science and its core concepts: levels of disagreement, pp. 205-235), um autor consagrado a quem se devem muitas das discussões teóricas na última década. Recuperando várias definições, este autor defende que não podemos começar por definir "informação", mas antes considerar qual o campo de conhecimento em que estamos a trabal har e qual o tipo de perspetiva teórica que melhor se enquadra para a nossa abordagem, continuando a tentar responder às questões: Quais as teorias que integram o conceito de informação? Quais as teorias que apresentam modelos conceptuais úteis para a ciência da informação? Sintetizando, refere que "there has been a tendency to regard natural sciences, especially physics, the ideal science and to borrow its concepts also in discourses about human and social issues. There is a clear ideological 
tendency and danger considering in human beings objects rather than subjects. This has been the case first with behaviourism, later with cognitive science, the field that made the concept of information and information processing central in many social sciences, including library and information science. There have been many debates about this, and I put myself in line with Frohman $(1990,2004)$ and Brier (2008) and thus consider alternatives such as discourse analysis and semiotics important alternatives to all theories derived from or associated with an objective understanding of information (as often associated with Shannon's information theory)." (p.233)

São ainda apresentados três casos, oferecendo uma leitura estimulante das evoluções paralelas da tecnologia, do discurso teórico e dos consumos/sentidos da informação e comunicação:

- Sylvie Leleu-Merviel - Visual information construing: bistability as a revealer of mediating patterns (pp.237-265), combinando inteligência informacional e a documentação audiovisual, propondo a renovação da construção do sentido através da mediação

- Michel Labour - Understanding user's informational constructs via a triadic method approach: a case study (pp. 267-296), combinando a literacia visual, constructos semicognitivos e abordagem comunicacional para estudar as dinâmicas e o sentido produzido pelos utilizadores

- Thomas Dousa - Documentary languages and the demarcation of information units in textual information: the case of Julius O. Kaiser's Systematic indexing (pp. 297-3..) apresentando a informação decomposta em unidades, signos e sequências, termos e frases enquanto unidades de informação e objeto de análise na teoria da indexação. A questão colocada "if one is going to characterize the information content of textual information, how does one identify and demarcate information units within text? é respondida através dos métodos de indexação de J.O Kaiser (1911), explorando a visão epistemológica e os constrangimentos comunicacionais das linguagens documentais.

Resta-me sublinhar, em jeito de conclusão, que vale a pena citar outro texto, que poderá enquadrar a pertinência deste tipo de discussões em Portugal, uma vez que se verifica ainda algum alheamento por parte dos profissionais da importância das abordagens de cariz mais teórico ou filosófico. Escrevia Andrew P. Carlin no início do seu artigo Segmented professions: further considerations of theory and practice in LIS and Librarianship (2009), o seguinte: «There is an equivocal relationship between the academic field of information studies and its practical application, the information professions. This is increasingly visible with regards to the proliferation of theories of information" ... However, I do not just argue that theorizing about information is important for LIS I also suggest that is important to consider the form and status of theorizing» (p.1). Em 2014, o mesmo autor confessa-se 
rendido a um dos mais importantes livros teóricos dos últimos anos, considerando Theories of information, communication and knowledge: a multidisciplinary approach, um excelente exemplo da viragem epistemológica da ciência da informação, recomendando a sua leitura a públicos variados. De facto, a pertinência e a importância deste trabalho está também no contributo para melhorar o conhecimento sobre a evolução das bases teóricas de um grupo profissional sobre o qual pouco se fala e muito se desconhece.

\section{Notas}

1 Os intervenientes no Colóquio são maioritariamente representantes da corrente de discussão europeia: Luciano Floridi, professor na Universidade de Oxford e Hertfrdshire; Birger Hjorland, professor na Royal School of Information Science em Copenhaga, Bruno Bachimot, Diretor Cientifico no INA e professor na Université de Technologie de Compiègne, Soren Brier, professor de semiótica na Copenhagen Business School, Sylvie LeleuMerviel, professora ma Université de Lille- Nord, Jean Davallon, professor en Sciences de l'information et de la Communcation na Université d' Avignon, Thomas Dousa, graduate School of Library and Information Science, université of Illinois e Ira Noveck do CNRS de Lyon. Posteriormente, foram convidados outros especialistas que integram o livro agora publicado.

2 Bates apresentou em 200513 metateorias para a área da Library and Information Science: a abordagem histórica; a abordagem construtivista, a abordagem construtivista, a abordagem filosófica, a abordagem teórico-crítica, a abordagem etnográfica, a abordagem sociocognitiva, a abordagem bibliométrica, a abordagem física, a abordagem da engenharia, a abordagem centrada no utilizador e a abordagem evolucionista.

\section{Referências bibliográficas}

ABBOTT, Andrew. (2001) - The chaos of disciplines. Chicago: The University of Chicago press.

BATES, Marcia J. (2005) - An introduction to metatheories, theories and models. In Fisher, K.E.; Erdelez, S. \& McKechnie, L. (eds.) Theories of information behaviour. Medford: Information Today

BATES, Marcia J. (2010) - Information In Encyclopedia of Library and Information Sciences. New York: Taylor and Francis, pp. 2347-2360

BAWDEN, David; ROBINSON, Lyn (2012) - Introduction to Information Science. London. Facet. 
CARLIN, Andrew P. (2009) - Segmented professions: further considerations of theory and practice in LIS and Librarianship. Library Philosophy and practice. (e-journal) Paper 294 [Consult. 1 jun. 2014]. Disponível em http://digitalcommons.unl.edu/libpilprac/294

CARLIN, Andrew P. (2014) - Book review. Journal of the association for information science and technology, 65 (6), 1299-1302

CORNELIUS, Ian (2002) - Theorizing information for information science. Annual review of information science and technology, vol. 36, pp. 392-425.

HARTEL, Jenna; FULLER, Steve; SZOSTAK, Rick; BONNICI, Laurie (2012) - The interdisciplinary study of information, ASIST 2012 Proceedings, October 28-31, Baltimore.

MACHLUP, Fritz; MANSFIELD, Una (Eds.) (1983) - The study of information: interdisciplinary messages. New York: Wiley.

NEILL, Samuel D. (1992) - Dilemmas in the study of information: exploring the boundaries of information science. New York: Greenwood.

IBEKWE-SAN JUAN, Fidelia; DOUSA, Thomas M. (Eds) (2014) - Theories of information, communication and knowledge: a multidisciplinary approach. Dordrecht. Springer, 380 pp. ISBN 978-94-007-6973-1

Paula Ochôa 